\title{
Calcareous nannofossil assemblage changes from early to middle Eocene in the Levant margin of the Tethys, central Israel
}

\author{
MENAHEM WEINBAUM-HEFETZ* \& CHAIM BENJAMINI \\ Department of Geological Environmental Sciences, Ben-Gurion University of the Negev, P.O.B. 653, Beer-Sheva 84105, Israel \\ *Corresponding author (e-mail: hefetzwe@bgu.ac.il)
}

\begin{abstract}
Patterns of change in calcareous nannofossil assemblages during nannozones NP11 to NP16 on the southern Levant margin of the Tethys were observed from sections of early and middle Eocene age sediments of the Avedat Plateau, central Israel. A cooling process following the Early Eocene Climate Optimum (EECO) is supported by several events of biotic change over a $4 \mathrm{Ma}$ interval. The rate of pelagic sedimentation varied from 7.5 at the EECO to $23.6 \mathrm{~m} \mathrm{Ma}^{-1}$ at the cooling transition phase. Reduced numbers of discoasters mark the end of the oligotrophic regime within the NP13 nannozone, followed by an increase in nannofossil richness especially marked by Blackites and Chiasmolithus spp. In the middle part of the cooling process a prominent peak of reworked Paleocene taxa, up to $7 \%$ of total taxa, suggests that enhanced current activity caused re-sedimentation on the Levant margin slopes. When stability resumed in the upper part of the NP15-16 interval, Coccolithus-type placoliths became rare and Reticulofenestra-type forms became dominant. Calcareous nannoplankton response to this gradual cooling became irreversible in the late Palaeogene, but the change was, however, diachronous across the Tethys. J. Micropalaeontol. 30(2): 129-139, September 2011.
\end{abstract}

KEYWORDS: Eocene, calcareous nannofossils, Levant, EECO, Tethys

\section{INTRODUCTION}

The early Eocene was marked by conditions of extreme Cenozoic warmth including the Early Eocene Climate Optimum (EECO) (Zachos et al., 2008), with a lack of polar-ice, warm tropical climates (Pearson et al., 2009) and low latitudinal temperature gradients (Bijl et al., 2009). Some have suggested that stagnant warm saline waters formed in low latitudes, particularly in the Tethyan realm (Kennett \& Stott, 1990). These early Eocene conditions of extreme warmth ended prior to the Ypresian/Lutetian (early/middle Eocene) boundary with the initiation of cooling, especially at high latitudes (Bijl et al., 2009). The early to late Eocene cooling trend is one of the most distinct climatic changes in the Cenozoic and appears to strongly influence the evolution of many microplankton groups (Bown, 2005; Ezard et al., 2011), forming the background for the evolution of many modern life forms, and is particularly well expressed in micropalaeontological studies.

Recent studies have stressed the sensitivity of coccolithophores to environmental change. Many researchers noted their biotic response to the dramatic changes of the early Cenozoic (e.g. Gibbs et al., 2006), hence the growing use of calcareous nannofossils as palaeoclimatic proxies. Agnini et al. (2006) tracked the early/middle Eocene transition at Possagno, Italy, and emphasized the rise of clade Noelrhabdaceae as marking the development of a major part of the modern oceanic phytoplankton community during this interval. Agnini et al. (2006) also considered the Discoasteraceae acme event, coincident with the EECO, to represent a peak of oligotrophic opportunists during these conditions of extreme warmth. Tremolada \& Bralower (2004) showed that the genus Chiasmolithus represents cooler and more nutrient-rich water.

Many studies have been carried out at the northern edges of the Tethyan realm (Fig. 1). Payros et al. $(2006,2007)$ established a biomagnetochronological scheme for the Gorrondatxe section in the Pyrenees. Molina et al. (2000) and Ortiz et al. (2008) have reviewed the Ypresian/Lutetian boundary in Agost, Spain, noting that the occurrence of Blackites inflatus is the most suitable marker event for this interval. These studies and others detail the response of calcareous nannofossils to early Cenozoic palaeoceanography, climatic change and rates of sedimentation. No similar studies have yet been carried out in the eastern Mediterranean Levant region. The current study is aimed at exploring oceanic change in this part of the Tethys, based on significant events in the calcareous nannofossil record, and correlating them to oceanic change elsewhere in the Tethys and beyond.

The Eocene strata of Israel were deposited off-shelf on the slope of the southern part of the Tethyan Ocean (Fig. 1). The typical lithology, divided into four formations, was described by Bentor \& Vroman (1963, 1964), and Braun (1967) (Figs 2, 3): the Mor Formation, chalk with chert nodules; the Nizzana Formation of chalk and limestone intercalations; the Horsha Formation, primarily of massive, friable chalk; and the Matred Formation of more indurated chalk intercalated with limestone. Benjamini $(1979,1980)$ studied field and microfacies relationships among these units as well as the zonal biostratigraphy using planktonic foraminifera, stressing that the pelagic section at Avedat was remarkably continuous and somewhat expanded. Benjamini $(1979,1980)$ showed that the intercalated limestones within the Nizzana and Horsha formations, rich in larger benthic foraminifera, are often mass-transported. A more detailed investigation of these phenomena in the central region of Israel was carried out by Buchbinder et al. (1988) and is under further study at present. Most transport phenomena found in the Avedat plateau are currently interpreted as muddy debris flows.

Paleocene and early Eocene calcareous nannofossils from the Avedat Plateau were studied by Romein (1979), who concentrated on the Paleocene and compared this section with similar ones from Spain and Scandinavia. Ehrlich \& Moshkovitz (1982) 


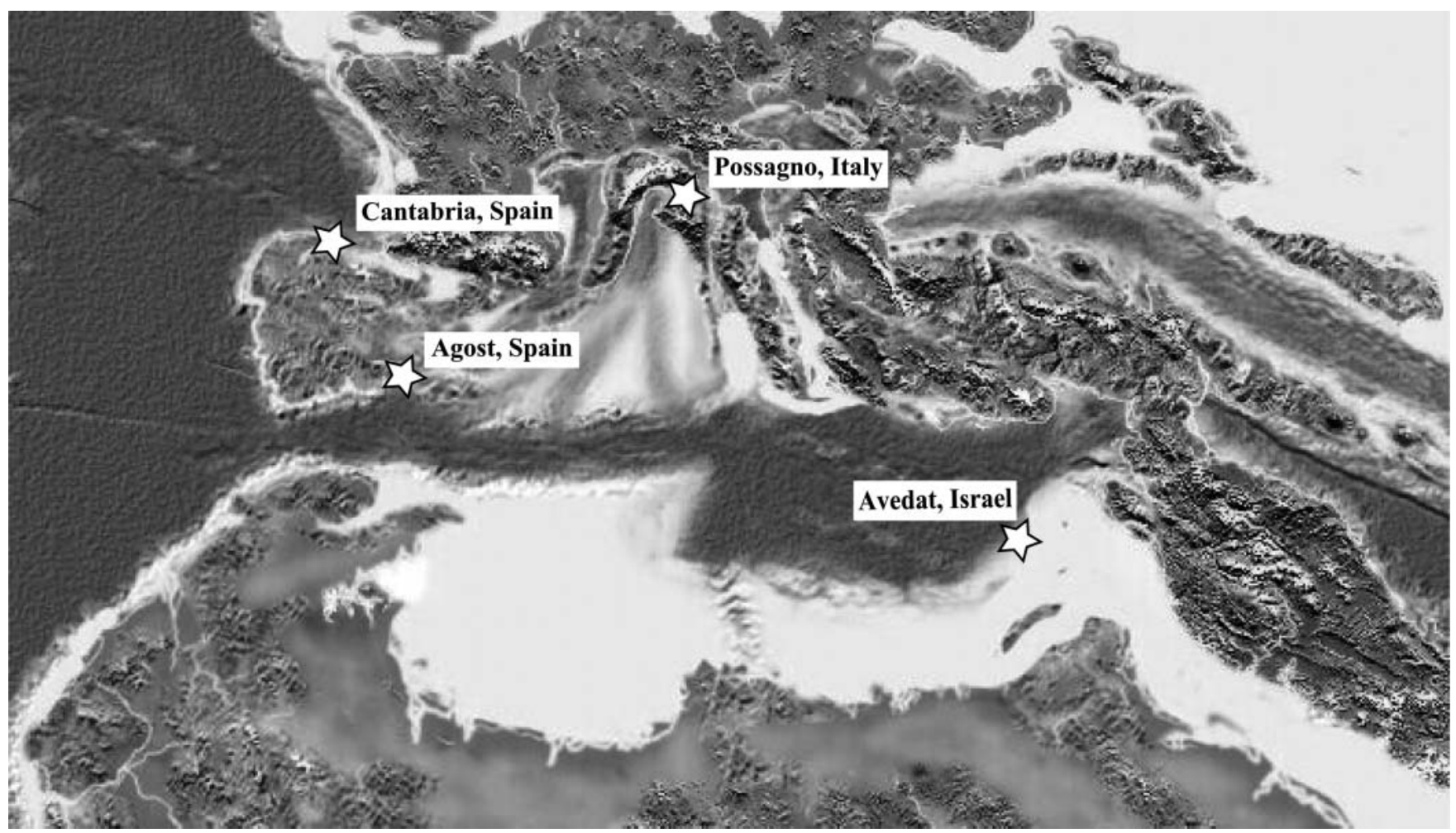

Fig. 1. Palaeogeographical map of southern Europe and the Mediterranean region in the Eocene. The locations of Agost and Cantabria, Spain together with Possagno in Italy are presented together with the location of the Avedat Plateau in the Levant region. (Source: http://www2.nau.edu/ rcb7/paleogeographic_alps.html.)

matched the nannofossil-based biostratigraphical scheme of the southern part of Israel with the NP system of Martini (1971). However, they proposed that Reticulofenestra umbilicus be used as the marker species for the NP15/NP16 boundary rather than Blackites ('Rhabdosphera') gladius (Perch-Nielsen, 1985). A multiple biostratigraphical correlation of the northern Negev sections, using planktonic foraminifera, nummulites and calcareous nannofossils, was presented by Moshkovitz (1995) and by Schaub et al. (1995).

\section{METHODS}

A total of $207 \mathrm{~m}$ of chalk section from seven sub-sections were sampled in the Avedat Plateau, some $50 \mathrm{~km}$ south of BeerSheva, southern Israel: four sites at the Ein Avedat National Park (labelled EA1-4), two sub-sections in the Borot Ramallieh hill (some $2.5 \mathrm{~km}$ to the south, labelled BR1,2) and one site at the Har Eldad roadcut (labelled EL). Locations of sections from the Avedat Plateau are shown in Figure 4. Outcrops were measured by Brunton and tape, and clean samples were taken at an average of $0.4-1.0 \mathrm{~m}$ interval. The continuity between subsections was made by measuring distances by theodolite, occasionally corrected by comparing the range-charts between sections.

In the laboratory, chalk samples were crushed to powder, then diluted in distilled water and ultrasonically disaggregated for five minutes. Without size segregation, a solids concentration of $70 \mu \mathrm{g} \mathrm{ml}^{-1}$ with about $10-20$ individual nannoforms per field of view, evenly distributed on a slide, was examined under plain polarized light (PPL) and by scanning electron microscopy
(SEM). Slides for optical examination were prepared from $650 \mu$ of suspension onto an $18 \times 18 \mathrm{~mm}$ cover glass, while for SEM microscopy $230 \mu \mathrm{l}$ of suspension was injected onto a $12 \mathrm{~mm}$ diameter round stub. Samples were dried at up to $60^{\circ} \mathrm{C}$ on a heating plate and glued by NOA61 optical adhesive. Samples were observed under Zeiss Photomicroscope II, PPL with CCD camera, in the sedimentology laboratory at BenGurion University of the Negev, and under the JEOL JSM-840 SEM at the Geological Survey of Israel in Jerusalem. Data processing used PRIMER 6.0 software and plots were made by LogPlot7.0.

\section{Biostratigraphy}

Three hundred fields of view were inspected from each sample. Full range charts were prepared for each sub-section and then combined to make up a composite chart. The stratigraphic position for each sample was located according to the First/Last Occurrence (FO/LO) of the zonal markers, following Romein (1979), Ehrlich \& Moshkovitz (1982), Perch-Nielsen (1985), Aubry (1986) and Moshkovitz (1995). The range charts were used as source data for the age model and for counting the number of species to obtain the richness indices of total nannofossils and Chiasmolithus spp. Sedimentation rates were calculated using the FOs/LOs of zonal marker species and nannofossil datum ages from the biostratigraphical scheme of IODP 320/321 report (Pälike et al., 2008) including the FO of R. umbilicus (and see Backman, 1987; Cande \& Kent, 1995). For the early-middle Eocene interval studied, this follows the time-scale of Cande \& Kent (1995). Some parts of the Avedat 
Calcareous nannofossil assemblage changes, central Israel
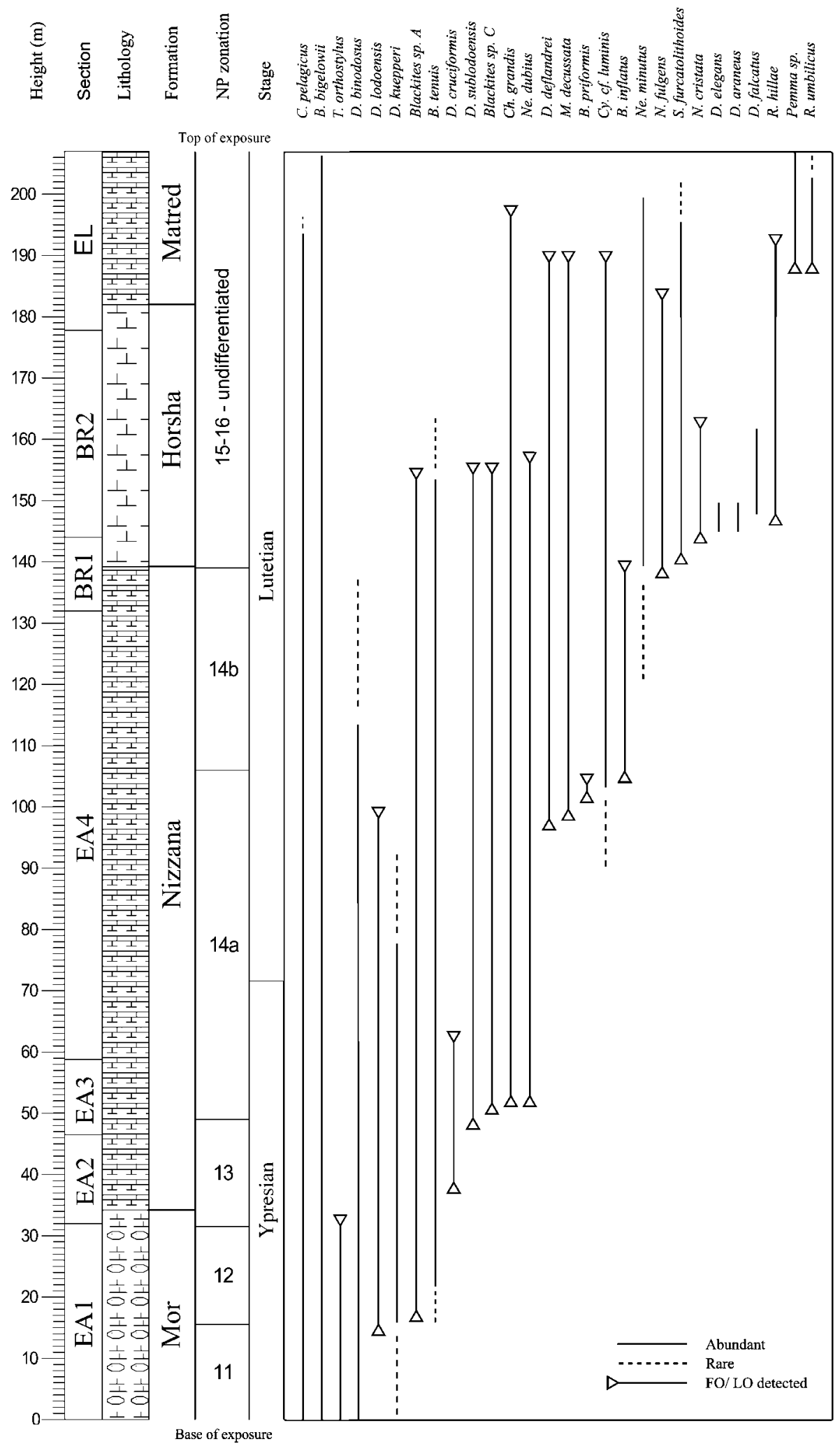

Fig. 2. Composite columnar section for the Avedat Plateau showing ranges of selected calcareous nannofossils. 


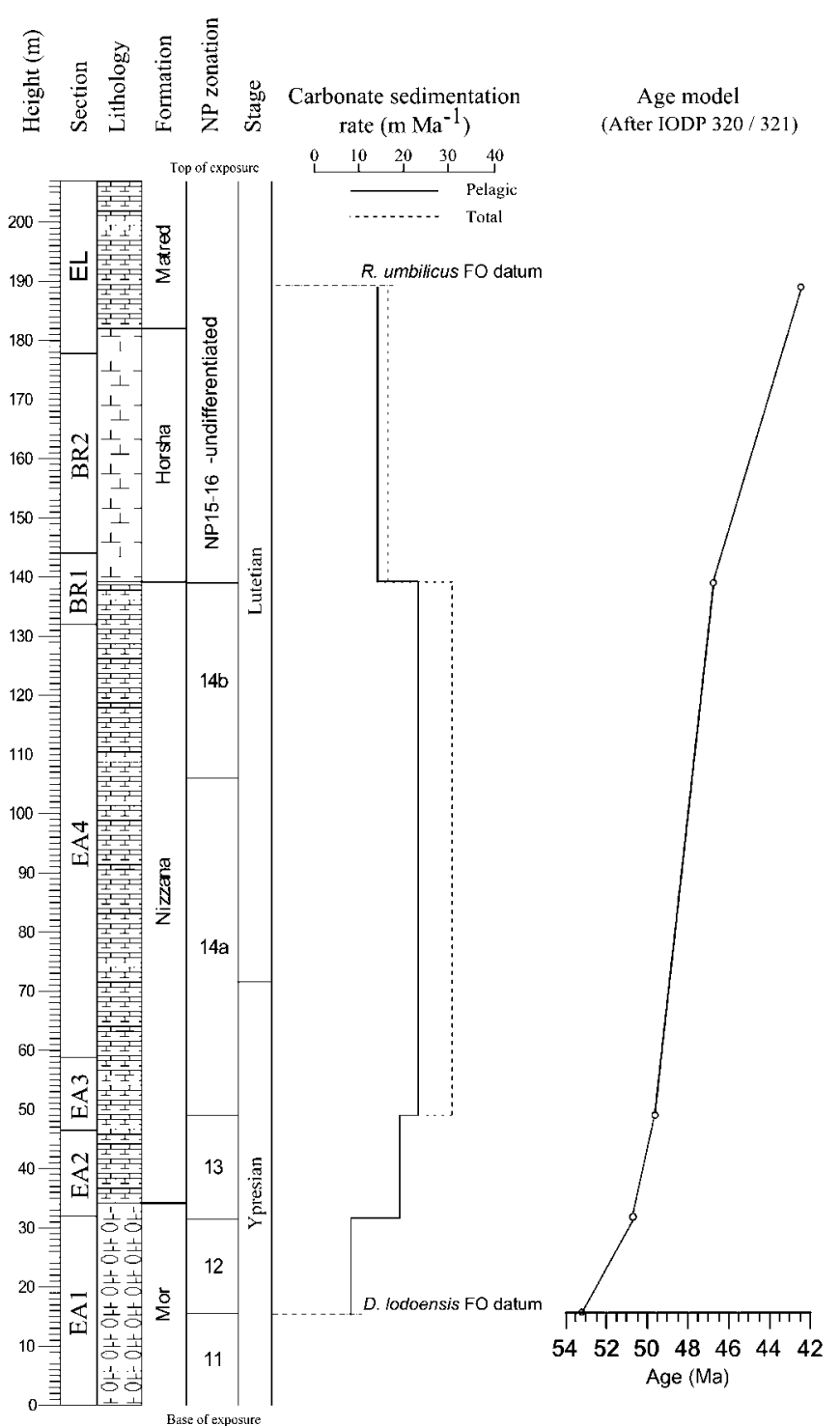

Fig. 3. Composite columnar section for the Avedat Plateau showing heights, lithology and NP zonation. Rates of sedimentation are correlated with heights. The regressions of height/age used for the age model are plotted. Time-scale from Pälike et al. (2008).

sections have mass-transport intercalations, averaging $25 \%$ of the measured sections. The rate of pelagic sedimentation was calculated by subtracting the thickness of these transported beds (Fig. 3). Sedimentation rates and ages of zonal markers were used to build the age model. EECO and the following cooling event were located using the digitized data of Zachos et al. (2001).

\section{Assemblage counts}

The current study aimed to test some known nannofossil forms for their usefulness as palaeoenvironmental indicators. For each slide, a total of 300 nannoforms was counted, from 10 slides with 3 repetitions. Error of counting was 5\%. The counting emphasized a number of selected nannofossil groups.

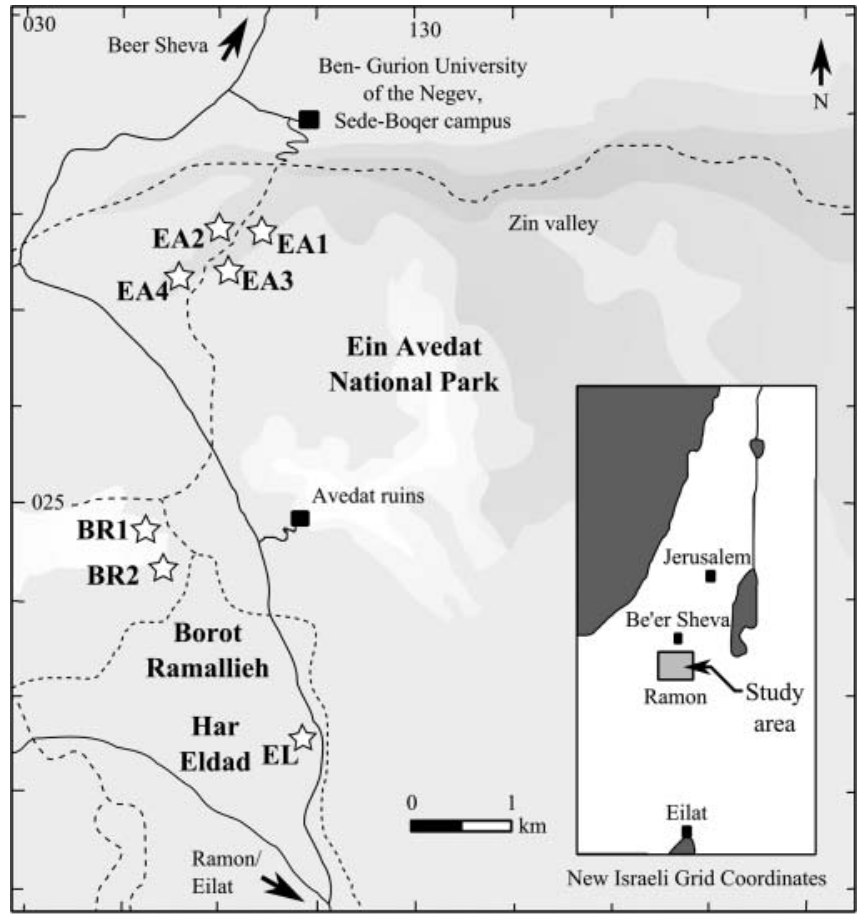

Fig. 4. Location of sub-sections in the Avedat Plateau, central Israel: EA1-EA4, Ein Avedat canyon sections; BR1-BR2, Borot Ramallieh hill sections; EL, Har Eldad road-cut section.

Genus Chiasmolithus Hay, Mohler \& Wade, 1966 is expected to be a proxy for cool nutrient-rich conditions. For this purpose the current study used the simple species richness index of Hammer \& Harper (2006, p. 187) of the number of species of Chiasmolithus within each sample.

Genus Discoaster Tan, 1927 represents warm saline oligotrophic conditions (Agnini et al., 2006).

Reticulofenestra vs. Coccolithus-types - Bown et al. (2004) established the phylogeny of coccolithophores in the Cenozoic. Two of the dominant placolith-forming coccolithophore families, the Coccolithaceae (including Coccolithus) and Noelrhabdaceae (including Reticulofenestra) show distinct patterns of diversification through the Palaeogene, which may be related to environmental conditions (Bown, 2005) and have their splitpoint early in the Palaeogene. Within the latter group, Agnini et al. (2006) traced the transition from Prinsiaceae to Noelrhabdaceae in the early/middle Eocene transition. Here, we have grouped those heterococcoliths into two forms basically differentiated by their optical characteristics; these have common symplesiomorphic characters that follow the nomenclature of Young \& Bown (1997) and Young et al. (1997). The Reticulofenestra-type have crystallographic units (V/R units, Young et al., 1997) that show strong bright birefringence under crossed polarized light (XPL). The Coccolithus-type has Coccolithus-type rim-structure and a darkened outer distal shield when viewed under XPL. The two distinct forms were counted under XPL, and 50 SEM images from each sample verified the diagnostic features.

Genus Blackites Hay \& Towe, 1962 emend. Stradner \& Edwards, 1968 - the increased diversity of this genus around the early/middle Eocene boundary has been noted by many 
authors (e.g. Bramlette \& Sullivan, 1961; Perch-Nielsen, 1985). Weinbaum-Hefetz et al. (2000) showed the wealth of forms and variants in the NP14 zone, and remarked on the difficulties of grouping them using a simple species-concept. Some forms are rare and occur in just a few samples (e.g. Blackites piriformis), whereas others are highly abundant (e.g. B. tenuis). For these reasons the current study used the natural-log H'(S) ShannonWiener index of diversity (Hammer \& Harper, 2006, p. 192) that depends both on the number of species and on the number of counted individuals.

Reworked taxa - several nannofossil species found in the NP14 and NP15 zones are typical for the Paleocene (Romein, 1979; Perch-Nielsen, 1985). These species belong to Ellipsolithus (e.g. E. macellus, Cruciplacolithus (e.g. Cr. cf. vanheckae, $\mathrm{Cr}$. subrotundus) and some discoasters (e.g. D. araneus, D. elegans). These species are interpreted as reworked taxa in the current study. The number of reworked taxa was standardized by the species richness index for each sample.

\section{RESULTS}

The calcareous nannofossils from the Avedat Plateau are normally well preserved, as mentioned by Romein (1979) and by Moshkovitz (1995). A few intervals display poor preservation, usually in proximity to thick chert horizons or dark chalks in the Mor Formation, or to the indurated chalks enclosing the mass-transported emplacement beds in the Nizzana and Matred formations. The most distinct transport events were in the EA4 section at $63 \mathrm{~m}, 110 \mathrm{~m}$, at BR2 at $145 \mathrm{~m}$, and EL at $185 \mathrm{~m}$, interrupting the continuity of the project data, as can be seen in Figure 5.

\section{Biostratigraphy}

A total of 103 nannofossil taxa was determined and placed into Palaeogene calcareous nannofossil zones NP11-NP15/16 (Martini, 1971; Okada \& Bukry, 1980). Species present are listed in Appendix A and some significant forms are shown in Figure 2. The rich calcareous nannoflora of the Avedat Plateau has already been illustrated by Moshkovitz (1995). A composite stratigraphy was constructed based on nannofossil and lithological correlations (Fig. 3), which spans Palaeogene calcareous nannofossil zones NP11-NP15/16 (Martini, 1971; Okada \& Bukry, 1980). The lithostratigraphic formations are subdivided into NP zones.

NP11. The Discoaster binodosus Zone, $15 \mathrm{~m}$ thick, was found in the Mor Formation. The base of this zone is not exposed.

NP12. The Tribrachiatus orthostylus Zone, $18 \mathrm{~m}$ thick in the Mor Formation. Its base is marked by the FO of D. lodoensis.

NP13. The Discoaster lodoensis Zone is $23 \mathrm{~m}$ thick and occurs in the lower part of the Nizzana Formation. Its base overlies the LO of $T$. orthostylus.

NP14. The Discoaster sublodoensis Zone is $85 \mathrm{~m}$ thick in the Nizzana Formation. The base of this zone is the FO of Discoaster sublodoensis. The top underlies the FO of Nannotetrina fulgens. The FO of Blackites inflatus marks the base of the NP14b subzone. Many inflated and curved-spine rhabdosphaerids occur within subzone NP14b, including B. piriformis. An increased variety of calcareous nannoforms was also found.

NP15-16 interval. The FO of Nannotetrina fulgens marks the base of NP15 and this species is present in an interval some $68 \mathrm{~m}$ thick. N. fulgens first occurs near the top of the Nizzana Formation (at $139 \mathrm{~m}$ ), continues through the Horsha Formation and terminates with the FO of Reticulofenestra umbilicus in the top $15 \mathrm{~m}$ of the composite section, within the Matred Formation. The FO of $R$. umbilicus falls within the NP16 zone. The criteria used for the definition of $R$. umbilicus followed Backman \& Hermelin (1986) and Gallagher (1989). Blackites gladius marking the base of NP16 was not found within this interval, in agreement with Ehrlich \& Moshkovitz (1982), so the NP15-16 interval was left undifferentiated (Fig. 2) with its top not exposed.

\section{Rate of sedimentation}

Figure 3 shows two calculations of sedimentation rates in the Avedat Plateau: the total and the pelagic carbonate sedimentation rate, calibrated against the Palaeogene time-scale of IODP 320/321 report (Pälike et al., 2008). The position of the EECO, subsequent cooling and stable thermal trend of the middle Eocene, following Zachos et al. (2001), are shown in Figure 5. The highest rates of sedimentation measured in the Avedat Plateau were in NP14 at $31.5 \mathrm{~m} \mathrm{Ma}^{-1}$, including the thickness of the transported beds, but $23.6 \mathrm{~m} \mathrm{Ma}^{-1}$ for the autochthonous, undisturbed chalks in that section.

Initial rate of sedimentation in early Eocene Zone NP12 was $7.5 \mathrm{~m} \mathrm{Ma}^{-1}$. The total rate increases to $19.2 \mathrm{~m} \mathrm{Ma}^{-1}$ in zone NP13 with an equal pelagic rate. A further increase in pelagic rate occurred in NP14 to $23.6 \mathrm{~m} \mathrm{Ma}^{-1}$. In NP15, both total and pelagic rates fall to 14.0 and $13.0 \mathrm{~m} \mathrm{Ma}^{-1}$, respectively. All in all, carbonate flux to the sediment is, therefore, rather moderate in the early Eocene, and increases two-fold in the middle Eocene, before stabilizing in NP15.

\section{Nannofossil assemblages}

The changing trends in population can be correlated with the main events surrounding the early/middle Eocene transition (Fig. 5). A general trend of increase is observed with the species richness index: from a number of species average of 15 within the Mor Formation (EA1 and EA2 sections, NP11 and 12) to a peak of 69 within the Borot Ramallieh (BR1 section) at 137$140 \mathrm{~m}$, correlated with $\sim 46.9-46.6 \mathrm{Ma}$, species richness then declines to a minimum of 11 . This time interval correlates with the cooling event of the early Lutetian. The pattern of Chiasmolithus species richness follows a similar trend: in NP11 and NP12 only Chiasmolithus solitus is found. The average number of species remains 2 until the NP14/NP15 boundary. At Borot Ramallieh (BR1 section) the number of species reaches a maximum of 8 at $142 \mathrm{~m}(\sim 46.7 \mathrm{Ma})$, and other species of this genus appear, e.g. Ch. medius, Ch. bidens and Ch. modestus. In the upper part of the section, in the Matred Formation (NP16), the number of species falls to 11 , with abundant $C h$. grandis.

Blackites diversity. Species present include B. tenuis, B. creber, B. scabrosus, B. inflatus, B. piriformis and others. During most of the early Eocene, and later in the middle Eocene, mostly $B$. tenuis is present and the Shannon-Wiener index is $0.00-0.69$. Across the early/middle Eocene (Ypresian/Lutetian) boundary, diversity of Blackites spp. increases sharply, levelling at 1.60 from 65-135 m (most of NP14) and decreases markedly during the early NP15 zone. A small peak might be present towards the 


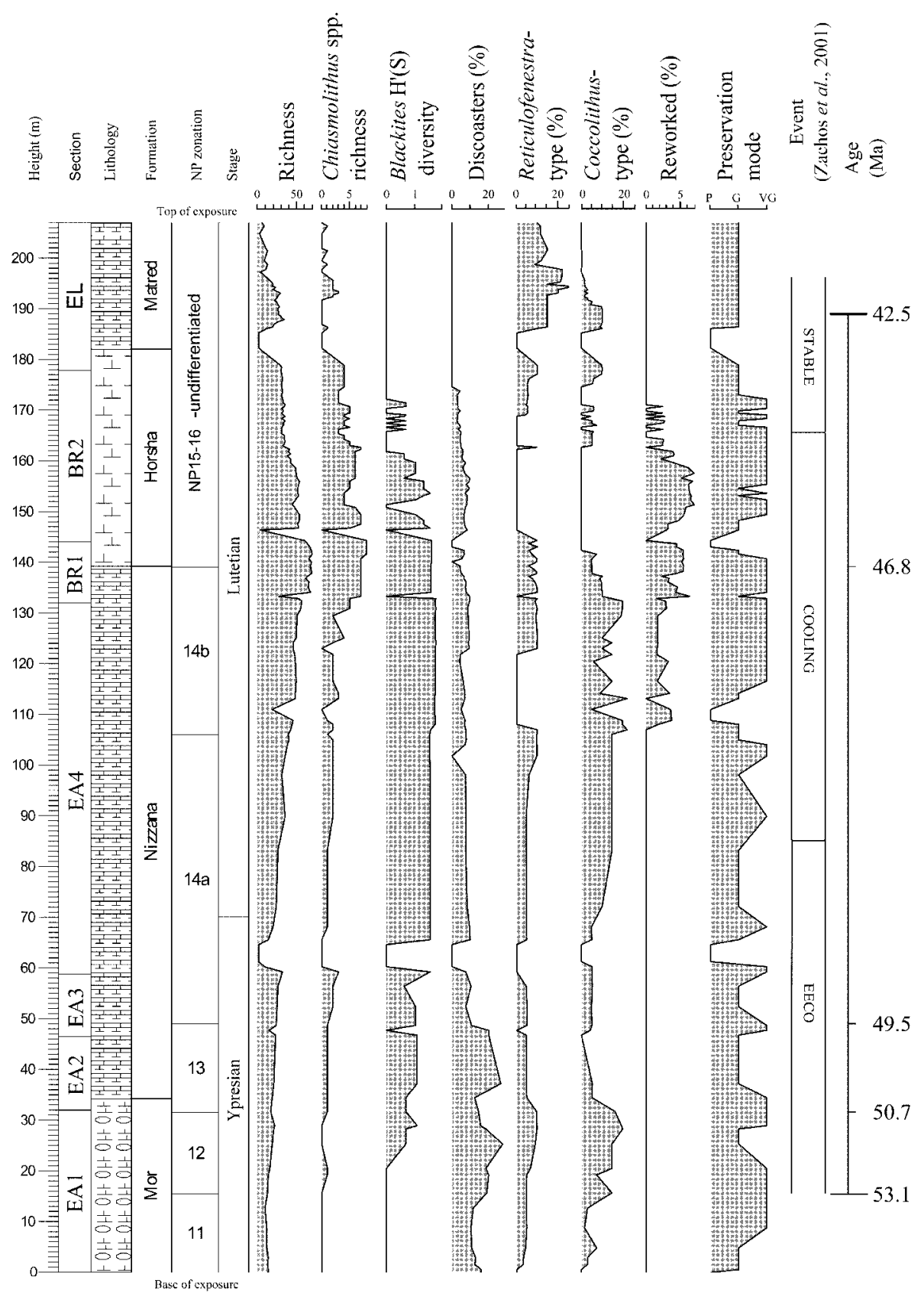

Fig. 5. Features of the calcareous nannofossil assemblages of the Avedat Plateau sections, calibrated against the Palaeogene time-scale (Pälike et al., 2008). The position of the Early Eocene Climatic Optimum (EECO), subsequent cooling and stable thermal trend of the Middle Eocene are after Zachos et al. (2001). Preservation mode: P, Poor; G, Good; VG, Very Good. Reworked species are standardized by the species richness index.

end of NP14b that could be correlated to the NP14/15 boundary and the behaviour of Blackites spp. is remarkably stable during the long NP14 interval.

In contrast to both Chiasmolithus and Blackites, the discoasters are more dominant in the lower parts of Ein Avedat section, with an average of $25 \%$ of total counts in the lower parts of Ein Avedat section. The discoaster climax, when they form $46 \%$ of the total, is at $25 \mathrm{~m}$, a position that correlates to $52.3 \mathrm{Ma}$, within the EECO interval. Thereafter, their abundance decreases gradually (allowing for horizons of poor preservation) through NP 14 and NP15/16 and shows no response to events at the
NP14/NP15 transition. No discoasters were found in the Matred Formation.

The dominant Reticulofenestra- and Coccolithus-type placoliths together have a baseline of an average $\sim 20 \%$ of total counts in almost equal proportions. This baseline is found in the interval from NP11 to NP13, with a slight advantage of the Coccolithus-type, but the Coccolithus-type becomes distinctly more dominant during zone NP14. Across the NP14/NP15 transition there is a fall in abundance of both forms, but they were, however, the only affected placoliths, as other heterococcolith-forms, such as Chiasmolithus, were abundant. 
The population of Reticulofenestra- and Coccolithus-types recovered in mid-NP15 (167 m, approximately $45 \mathrm{Ma})$ but significant turnover occurred around, and including, the first occurrence of $R$. umbilicus with the Reticulofenestra-type forms becoming abundant, while Coccolithus-type forms are sharply reduced. The upper part of the NP15-16 interval has mostly braarudosphaerids (e.g. Pemma sp.) and reticulofenestrids, but no Coccolithus-type placoliths.

Reworked taxa. Reworked taxa occur to some extent through most of the section, but counts are negligible $(<1 \%)$. By the early Lutetian, at $108 \mathrm{~m}$ in the EA4 section (base of NP14b subzone), they increase to around $2 \%$ of the total and then increase sharply to $6.9 \%$ at $145-160 \mathrm{~m}$ at Borot Ramallieh (BR2), in the Horsha Formation. (This position correlates to 46.5-45.5 Ma). Reworked taxa disappear in the uppermost Horsha Formation and were not found in the Matred Formation (i.e. from the FO of R. umbilicus datum and upwards).

\section{DISCUSSION}

The clear FOs of D. sublodoensis, $N$. fulgens and R. umbilicus, as well as the FO of inflated Blackites forms (B. inflatus and $B$. piriformis) highlights the similarity of the Avedat section to the Basque-Cantabrian sections (Bernaola et al., 2006). The early/ middle Eocene (Ypresian/Lutetian) boundary was located much higher by Benjamini (1980) and Schaub et al. (1995), at Borot Ramallieh at $175 \mathrm{~m}$, within the Horsha Formation. At that point the first appearance of the planktic foraminifera Hantkenina nutalli, in the upper part of nannozone NP15 was observed. This remarkable difference of $\sim 2.5 \mathrm{Ma}$ between the early/middle Eocene boundaries as defined by calcareous nannofossils vs. planktic foraminifera was noted by Benjamini (1980) and by Moshkovitz (1995).

\section{Sedimentation and reworking}

Pelagic sedimentation rate changes at Avedat, after deletion of the thickness of the transported beds, range from 7.5$23.6 \mathrm{~m} \mathrm{Ma}^{-1}$. The rate of sedimentation during the EECO is at first (NP11) relatively low, but more than doubles in the latter part, in NP12 and NP13. The cooling trend terminating the EECO in NP14 is accompanied by a three-fold increase in sedimentation rate, and increased carbonate production continues to the NP14/NP15 boundary. Maximum sedimentation rates of $20-30 \mathrm{~m} \mathrm{Ma}^{-1}$ correspond to the highest rates reported for clean pelagic sediments (Berner, 1980). The friable, clay-free chalks at Avedat are composed of nearly $80 \%$ calcareous nannofossils, with the remainder mostly planktonic foraminifera; as the P/B ratios are extremely high (Fermont, 1982), benthic foraminifera, bioclasts and siliceous material are minor components. Therefore, the rate of sedimentation in the Avedat Plateau represents a significant pelagic carbonate flux during the transitional phase of NP14, until NP15. In the Horsha Formation (lower NP15-16) rates appear to stabilize. At the NP14/ NP15 boundary the significant fall in carbonate production corresponds to the stabilization of the thermal regime, but to a rate that is still twice that of the later part of the early Eocene.

These sedimentation rates in nannozones NP 14 and NP15 are considerably higher than those of the more indurated deep marine marly limestones of Possagno (Agnini et al., 2006) for the same time intervals. Higher rates of $80-150 \mathrm{~m} \mathrm{Ma}^{-1}$, about four times that of the Avedat Plateau, were given for the Pamplona and Basque basins (Bernaola et al., 2006). However, these uniquely high sedimentation rates are over an order of magnitude greater than typical deep-sea sections and can be attributed to the presence of a significant allochthonous contribution.

A brief interval in which reworked Paleocene nannoforms appear in Eocene nannozones was also reported by Schaub et al. (1995) and was considered to be of local origin. The source for reworked silt-size sediments including calcareous nannofossils could, in fact, be from anywhere in the adjacent Tethyan margins. Nevertheless, Eocene beds high on the Ramon structure some $25 \mathrm{~km}$ to the south locally overlie strata of various ages, some as early as Cenomanian, as summarized in Benjamini (1979). Easily eroded Paleocene hemipelagic marls in the vicinity of the Ramon structure are most likely the source. These marls are extremely uniform over the entire Levant region and the point source is difficult to identify (Speijer, 1995).

The $\sim 7 \%$ reworked material has a minor effect on the rate of sedimentation, but the temporally limited nature of this reworking event suggests a connection to the cooling event of the early/middle Eocene transition. Localization of the peak (at $149-157 \mathrm{~m}$ in the composite section) to the end of the postEECO cooling trend can be explained by concomitant increased current activity that enhanced redeposition of oceanic sediments in the Levant region.

\section{Nannofossil assemblages}

There appear to be four distinct periods of nannofossil assemblage change across the studied early to middle Eocene succession. First, in the early Eocene age Mor and lower Nizzana formations (NP11-13), assemblages are characterized by relatively high proportions of discoasters. A similar peak in discoaster abundance, broadly coincident with the EECO, has been observed in other Tethys sections (Agnini et al., 2006). Based on the generally accepted preference of the discoasters for warmoligotrophic conditions, this would indicate that more stratified and less productive waters were widespread in the Tethys during the EECO and declined when cooling introduced nutrients and mixing.

The next interval is marked by the rise in diversity of the genus Blackites across the early/middle Eocene boundary. They then reached a diversity climax by the end of the EECO that remained steady throughout the relatively long NP14 interval. The Shannon-Wiener index of diversity shows that this increase is not controlled by changes in other nannofossil groups. This peak in Blackites diversity in the middle Eocene, flourishing during a time of climatic change, may be driven by the evolutionary diversification of this group around the early/middle Eocene transition, but causes of this diversification are not well understood.

The third interval is characterized by the clear rise in the species diversity within the genus Chiasmolithus, a genus which is considered to favour cooler and probably more nutrient-rich water (Tremolada \& Bralower, 2004). It thus appears that the increasing nannofossil diversity is linked to the pattern of gradual global cooling after the extreme warmth of the EECO.

The final interval begins with declines in the total nannofossil species diversity, Chiasmolithus diversity and Blackites diversity 
within the NP15-16 interval in the Matred Formation. The diversity of Chiasmolithus spp. declines after the passage of the cooling event, reflecting the final stage of stabilized surface water conditions in the Levant region.

\section{Reticulofenestra- vs. Coccolithus-type dominance}

The dramatic transition in dominance from the Coccolithus-type to the Reticulofenestra-type placoliths takes place close to the NP15/16 boundary in the basal Matred Formation ( 44.5 Ma). This is also associated with the global first appearance of the large reticulofenestrid, $R$. umbilicus and appears to be an important moment in the establishment of 'modern' reticulofenestrid-dominated coccolithophore assemblages. This event is considerably later than the transition from Toweius- to Reticulofenstra-dominated assemblages at Possagno, which is associated with the discoaster acme and occurs between $50 \mathrm{Ma}$ and $51 \mathrm{Ma}$, well within the early Eocene. The switch from Coccolithus-type to Reticulofenestra-type placoliths occurs some $4 \mathrm{Ma}$ later at Avedat, close to the first appearance of the planktic foraminifera Hantkenina nuttalli Tourmarkine 1981. Agnini et al. (2006) suggested that the change to the successful Noelrhabdaceae reflects a permanent and irreversible transformation of the way calcareous nannofossils interacted with the ocean-atmosphere system. This change occurred at the EECO in the northern Tethys, and much later in lower latitudes. The data from Avedat show that this was a progressive transition that took place during the Eocene, including a number of key points at which the dominance of the Noelrhabdaceae increased markedly, through to the restructuring of nannofossil communities at the Eocene/Oligocene boundary (Dunkley Jones et al., 2008).

\section{CONCLUSIONS}

The early Eocene of the Levant region was characterized by oligotrophic conditions, particularly during the EECO. Rates of sedimentation during the EECO were similar to those calculated in higher latitudes (Possagno, Italy). The dominant calcareous nannofossil taxa were low diversity Coccolithus-type placoliths and discoasters, both adapted to high temperatures, stable water stratification and, potentially, high $\mathrm{pCO}_{2}$ levels (Henderiks \& Rickaby, 2007).

Rates of sedimentation increased substantially just prior to the early/middle Eocene transition, and remained high during the post-EECO cooling trend. This interval was accompanied by an increase in the diversity of Blackites spp. as well as in the total number of nannoplankton species. These climatic changes reflect termination of the highly stratified super-greenhouse world of the early Eocene, replaced by a mixed water column structure with significant current activity that caused much re-sedimentation on Levant margin slopes.

From the EECO peak, decline of oligotrophy and enrichment of nutrients near the ocean surface was enhanced at the high latitudes of the northern edge of the Tethys, relative to the lower latitudes of the southern Tethyan margin. Towards the top of the studied section, in the Horsha and Matred formations, NP15 witnessed climatic stabilization. Under these conditions Blackites diversity decreased, as did the species richness of nannoplankton assemblages and the rise of Reticulofenestra-type placoliths was enhanced.
The transformation from Coccolithus-type dominance to Reticulofenestra-type placoliths took place at Avedat at the NP15/NP16 transition, around $4 \mathrm{Ma}$ later than at Possagno, Italy. The temporal discrepancy of this changeover is significant, in contrast to the preceding NP12 discoaster acme and subsequent decline that were coeval in both locations. The Possagno palaeoposition was at the northern edge of the Tethys, whereas the Levant margin at that time was at least $15^{\circ}$ south of its current latitude. This indicates the difference in palaeoceanographic conditions between the northern and the southern Tethys so that the turnover (expressed by cooling and nutrient enrichment) was highly diachronous and first occurred in the northern parts of the Tethys. This diachrony corroborates the observation of Pearson et al. (2009) that cooling begins primarily at the poles and influences the tropical belts only at later stages.

In fact, the middle Eocene cooling event has not particularly been considered by most workers on the Tertiary as a significant part of the mid-Tertiary global cooling trend, although global climate curves clearly show a consistent decline from the EECO to the Middle/Late Eocene transition, prior to the steep decline culminating at the onset of the Oligocene. We consider that the calcareous nannoplankton response to development of cooler water layers in the Tethys in the middle Eocene set the stage for their subsequent response at the late Eocene-early Oligocene global changeover. Had the later events not resulted in such extreme global cooling, the transition may not have been irreversible, and the middle Eocene placolith turnover may then have been a short-lived event.

\section{Manuscript received 20 December 2011 \\ Manuscript accepted 15 June 2011}

Scientific editing by Tom Dunkley Jones

\section{APPENDIX A: LIST OF SPECIES}

Birkelundia staurion (Bramlette \& Sullivan, 1961) Perch-Nielsen, 1971

Blackites creber Deflandre, 1954

Blackites inflatus Bramlette \& Sullivan, 1961

Blackites scabrosus Deflandre, 1954

Blackites sp. A

Blackites sp. C

Blackites piriformis (Pavsic in Khan et al., 1975) Aubry, 1999

Blackites tenuis Bramlette \& Sullivan, 1961

Braarudosphaera bigelowii Deflandre, 1947

Calcidiscus sp. B

Calcidiscus sp. A

Campylosphaera dela (Bramlette \& Sullivan, 1961) Hay \&

Mohler, 1967

Chiasmolithus bidens (Bramlette \& Sullivan, 1961) Hay \&

Mohler, 1967

Chiasmolithus consuetus (Bramlette \& Sullivan, 1961) Hay \& Mohler, 1967

Chiasmolithus expansus (Bramlette \& Sullivan, 1961) Gartner, 1970

Chiasmolithus grandis (Bramlette \& Riedel, 1954) Radomski, 1968 
Chiasmolithus modestus Perch-Nielsen, 1971

Chiasmolithus solitus (Bramlette \& Sullivan, 1961) Locker, 1968

var. A

Chiasmolithus solitus (Bramlette \& Sullivan, 1961) Locker, 1968

var. B

Chiasmolithus sp. cf. Ch. medius Perch-Nielsen, 1971

Coccolithus pelagicus (Wallich, 1877) Schiller, 1930

Cruciplacolithus cf. Cr. edwardsii Romein, 1979 var. A

Cruciplacolithus cf. Cr. edwardsii Romein, 1979 var. B

Cruciplacolithus sp. cf. Cr. frequens (Perch-Nielsen, 1971)

Romein, 1979

Cruciplacolithus cruciformis (Hay \& Towe, 1962) Roth, 1970

Cruciplacolithus sp. cf. Coccolithus sp. of Sullivan, 1964

Cruciplacolithus sp. cf. Cr. vanheckae Perch-Nielsen, 1986

Cruciplacolithus subrotundus Perch-Nielsen, 1969

Cyclicargolithus cf. luminis Sullivan, 1965

Cyclococcolithus sp.

Dictyococcites sp.

Discoaster araneus Bukry, 1971

Discoaster barbadiensis Tan, 1927 emend. Bramlette \& Riedel, 1954

Discoaster binodosus Martini, 1958

Discoaster cruciformis Martini, 1958

Discoaster deflandrei Bramlette \& Riedel, 1954

Discoaster distinctus Martini, 1958

Discoaster elegans Bramlette \& Sullivan, 1961

Discoaster falcatus Bramlette \& Sullivan, 1961

Discoaster gemmifer Stradner, 1961

Discoaster germanicus Martini, 1958

Discoaster incomptus Hay, 1967

Discoaster kuepperi Stradner, 1959

Discoaster lodoensis Bramlette \& Riedel, 1954

Discoaster pacificus Haq, 1969

Discoaster sp.

Discoaster sp. cf. D. trinus Stradner, 1961

Discoaster sublodoensis Bramlette \& Sullivan, 1961

Ellipsolithus lajollaensis Bukry \& Percival, 1971

Ellipsolithus macellus (Bramlette \& Sullivan, 1961) Sullivan, 1964

Ericsonia sp. A

Ericsonia sp. B

Helicosphaera lophota Bramlette \& Sullivan, 1961

Helicosphaera seminulum Bramlette \& Sullivan, 1961

Lophodolithus nascens Bramlette \& Sullivan, 1961

Lophodolithus renifornis Bramlette \& Sullivan, 1961

Lophodolithus rotundus Bukry \& Percival, 1971

Micrantholithus crenulatus Bramlette \& Sullivan, 1961

Micrantholithus flos Deflandre, 1950

Micrantholithus vesper Deflandre, 1950

Micula decussata Vekshina, 1959

Nannotetrina cristata (Martini, 1958) Perch-Nielsen, 1971

Nannotetrina fulgens (Stradner, 1960) Achuthan \& Stradner, 1969

Neochiastozygus digitosus Perch-Nielsen, 1971

Neochiastozygus distentus (Bramlette \& Sullivan, 1961) Perch-

Nielsen, 1971

Neococcolithes dubius (Deflandre, 1954) Black, 1967

Neococcolithes minutus (Perch-Nielsen, 1967) Perch-Nielsen, 1971
Pemma sp.

Pontosphaera distincta (Bramlette \& Sullivan, 1961) Roth \& Thierstein, 1972 var. A

Pontosphaera distincta (Bramlette \& Sullivan, 1961) Roth \& Thierstein, 1972 var. B

Pontosphaera enormis (Locker, 1967) Perch-Nielsen, 1984

Pontosphaera sp. A

Pontosphaera versa (Bramlette \& Sullivan, 1961) Sherwood, 1974 var. A

Pontosphaera versa (Bramlette \& Sullivan, 1961) Sherwood, 1974 var. B

Pseudotriquetrorhabdulus inversus (Bukry \& Bramlette, 1969) Wise \& Constans, 1976

Reticulofenestra conuera (Reinhardt, 1966) Roth, 1970

Reticulofenestra dictyoda (Deflandre \& Fert, 1954) Stradner, 1968

Reticulofenestra hillae Bukry \& Percival, 1971

Reticulofenestra samodurovii (Hay, Mohler \& Wade, 1966) Roth, 1970

Reticulofenestra scissura Hay, Mohler \& Wade, 1966

Reticulofenestra scripasse (Bukry \& Percival, 1971) Roth, 1973

Reticulofenestra umbilicus (Levin, 1965) Martini \& Ritzkowski, 1968

Scapholithus sp.

Scyphosphaera sp. A

Scyphosphaera sp. B

Sphenolithus editus Perch-Nielsen, 1978

Sphenolithus furcatolithoides Locker, 1967

Sphenolithus radians Deflandre, 1952

Sphenolithus sp. A

Sphenolithus sp. B

Thoracosphaera heimii (Lohmann, 1919) Kamptner, 1941

Thoracosphaera prolata Bukry \& Bramlette, 1969

Thoracosphaera saxea Stradner, 1961

Thoracosphaerae tuberosa Kamptner 1963

Transversopontis exilis (Bramlette \& Sullivan, 1961) PerchNielsen, 1971

Transversopontis fimbriatus (Bramlette \& Sullivan, 1961) Locker, 1968

Transversopontis latus Müller, 1970

Transversopontis obliquipons (Deflandre, 1952) Hay, Mohler \& Wade, 1966

Transversopontis rectipons (Haq, 1968) Roth, 1970

Transversopontis sigmoidalis Locker, 1967

Tribrachiatus orthostylus Shamrai, 1963 var. A

Tribrachiatus orthostylus Shamrai, 1963 var. B

Zygrhablithus bijugatus Deflandre, 1959

\section{ACKNOWLEGEMENTS}

Data for this research appear in the MSc thesis of the senior author, supervised by S. Moshkovitz (Geological Survey of Israel) and by C. Benjamini (Ben-Gurion University of the Negev). D. Korngreen (Geological Survey of Israel) provided useful advice. M. Dvorachek (Geological Survey of Israel) assisted with the SEM work. This project was supported by grants from the Israeli Ministry of National Infrastructures. We also wish to thank T. Dunkley Jones and anonymous reviewers for their useful comments that helped improve the manuscript. 


\section{REFERENCES}

Agnini, C., Muttoni, G., Kent, D.V. \& Rio, D. 2006. Eocene biostratigraphy and magnetic stratigraphy from Possagno, Italy: The calcareous nannofossil response to climate variability. Earth and Planetary Science Letters, 241: 815-830.

Aubry, M-P. 1986. Paleogene calcareous nannoplankton biostratigraphy of north-western Europe. Palaeogeography, Palaeoclimatology, Palaeoecology, 55: 267-334.

Backman, J. 1987. Quantitative Calcareous Nannofossil Biochronology of Middle Eocene through Early Oligocene sediment from DSDP sites 522 and 523. Abhandlungen der Geologische Bundesanstalt, 39: 21-31.

Backman, J. \& Hermelin, J.O.R. 1986. Morphometry of the Eocene nannofossil Reticulofenestra umbilicus lineage and its biochronological consequences. Palaeogeography, Palaeoclimatology, Palaeoecology, 57:103-116.

Benjamini, C. 1979. Facies relationships of the Avedat Group (Eocene) in the northern Negev, Israel. Israeli Journal of Earth Science, 28: 47-69.

Benjamini, C. 1980. Planktic foraminifera of the 'Avedat Group' (Eocene). Journal of Palaeontology, 54: 325-358.

Bentor, Y. \& Vroman, A. 1963. The Geological map of Israel 1:100000, sheet 17, Nizzana. Geological Survey of Israel.

Bentor, Y. \& Vroman, A. 1964. The Geological map of Israel 1:100000, sheet 19, Mt. Lots. Geological Survey of Israel.

Bernaola, G., Orue-Etxebarria, X., Payros, A., Dinarès-Turell, J., Tosquella, J., Apellaniz, E. \& Caballero, F. 2006. Biomagnetostratigraphic analysis of the Gorrondatxe section (Basque Country, western Pyrenees): its significance for the definition of the Ypresian/Lutetian boundary stratotype. Neues Jahrbuch fur Geologie und Palaontologie Abhandlungen, 241: 67-109.

Berner, R.A. 1980. Early Diagenesis: A Theoretical Approach. Princeton University Press, Princeton, N.J., 241pp.

Bijl, P.K., Schouten, S., Sluijs, A., Reichart, G.-J., Zachos, J.C. \& Brinkhuis, H. 2009. Early Palaeogene temperature evolution of the southwest Pacific Ocean. Nature, 461: 776-779.

Bown, P.R. 2005. Calcareous nannoplankton evolution: a tale of two oceans. Micropaleontology, 51: 299-308.

Bown, P.R., Lees, J.A. \& Young, J.R. 2004. Calcareous nannoplankton evolution and diversity through time. In: Thierstein, H. \& Young, J.R. (Eds), Coccolithophores: From Molecular Processes to Global Impact. Springer-Verlag, Berlin-Heidelberg, pp. 481-508.

Bramlette, M.N. \& Sullivan, F.R. 1961. Coccolithophorids and related nannoplankton of the early Tertiary in California. Micropaleontology, 7: 129-188.

Braun, M. 1967. Type sections of Avedat Group Eocene formations in the Negev (southern Israel). Geological Survey of Israel, Stratigraphic sections, No. 4.

Buchbinder, B., Benjamini, C., Mimran, Y. \& Gvirtzman, G. 1988 Mass transport in Eocene pelagic chalk on the north-western edge of the Arabian platform, Shefela area, Israel. Sedimentology, 35: 257274.

Cande, S.C. \& Kent, D.V. 1995. Revised calibration of the geomagnetic polarity timescale for the Late Cretaceous and Cenozoic. Journal of Geophysical Research, 100(B4): 6093-6095.

Dunkley Jones, T., Bown, P.R., Pearson, P.N., Wade, B.S., Coxall, H.K. \& Lear, C.H. 2008. Major shifts in calcareous phytoplankton assemblages through the Eocene-Oligocene transition of Tanzania and their implications for low-latitude primary production. Paleoceanography, 23: PA4204, doi: 10.1029/2008PA001640.

Ehrlich, A. \& Moshkovitz, S. 1982. Paleogene calcareous nannofossil biozonation in Israel. Geological Survey of Israel, Current Research, 1981: $35-41$

Ezard, T.H.G., Aze, T., Pearson, P.N. \& Purvis, A. 2011. Interplay between changing climate and species' ecology drives macroevolutionary dynamics. Science, 332: 349-351.

Fermont, W.J.J. 1982. Discocyclinidae from Ein Avedat (Israel). Utrecht Micropaleontological Bulletins, 27: 1-152.

Gallagher, L. 1989. Reticulofenestra: A critical review of taxonomy, structure and evolution. In: Crux, J.A. \& van Heck, S.E. (Eds), Nannofossils and their applications, The British Micropalaeontological Society, Ellis Horwood Limited, pp. 41-75.
Gibbs, S., Bralower, T.J., Bown, P.R., Zachos, J.C. \& Bybell, L.M. 2006. Shelf and open-ocean calcareous phytoplankton assemblages across the Paleocene-Eocene Thermal Maximum: Implications for global productivity gradients. Geology, 34: 233-236.

Hammer, Ø. \& Harper, D. 2006. Paleontological Data Analysis. Blackwell Publishing, Oxford, 351pp.

Henderiks, J. \& Rickaby, R.E.M. 2007. A coccolithophore concept for constraining the Cenozoic carbon cycle. Biogeosciences, 4: 323-329.

Kennett, J.P. \& Stott, L.D. 1990. Proteus and Proto-oceanus: Ancestral Paleogene oceans as revealed from Antarctic stable isotopic results; ODP LEG 113. In: Barker, P.F. \& Kennett, J.P. (Eds), Proceedings of the Ocean Drilling Program, Scientific Results, 113: 865-879.

Martini, E. 1971. Standard Tertiary and Quaternary calcareous nannoplankton zonation, In: Farrinacci, A. (Ed.), Proceedings of the Second Planktonic Conference, Roma. Edizioni Tecnoscienza, Rome, pp. 739-785.

Molina, E., Cosovic, V., Gonzalvo, C. \& Von-Salis, K. 2000. Integrated biostratigraphy across the Ypresian/Lutetian boundary at Agost, Spain. Revue de Micropaléontologie, 43: 381-391.

Moshkovitz, S. 1995. Calcareous nannofossils from the Lower Tertiary nummmulitic beds of the Negev. In: Schaub, H., Benjamini, C. \& Moshkovitz, S. (Eds), The Biostratigraphy of the Eocene in Israel, part IV. Schweizerischen Paleontologischen Abhandlungen, 117: 41-46.

Okada, H. \& Bukry, D. 1980. Supplementary modification and introduction of code numbers to the low-latitude coccolith biostratigraphic zonation (Bukry, 1973; 1975). Marine Micropaleontology, 5: 321-325. Ortiz, S., Gonzalvo, C., Molina, E., Rodríguez-Tovar, F.J., Uchman, A., Vandenberghe, N. \& Zeelmaekers, E. 2008. Palaeoenvironmental turnover across the Ypresian-Lutetian transition at the Agost section, Southastern Spain: In search of a marker event to define the Stratotype for the base of the Lutetian Stage. Marine Micropaleontology, 69: 297-313.

Pälike, H., Lyle, M., Nishi, H., Raffi, I., Gamage, K. \& Klaus, A. \& the Expedition 320/321. 2008. Pacific equatorial age transect. Proceedings IODP, Scientific Prospectus Volume, 320/321: Methods. doi: 10.2204/ iodp.proc.320321.102.2010.

Payros, A., Bernaola, G., Orue-Etxebarria, X., Dinars-Turrel, J., Tosquella, J. \& Apellaniz, E. 2007. Reassessment of the Early-Middle Eocene biomagnetochronology based on evidence from the Gorrondatxe section (Basque Country, western Pyrenees). Lethaia, 40: 183195.

Payros, A., Orue-Etxebarria, X. \& Pujalte, V. 2006. Covarying sedimentary and biotic fluctuations in Lower-Middle Eocene Pyrenean deepsea deposits: Palaeoenvironmental implications. Palaeogeography, Palaeoclimatology, Palaeoecology, 234: 258-276.

Pearson, P.N., van Dongen, B.E., Nicholas, C.J., Pancost, R.D., Schouten, S., Signano, M.J. \& Wade, B.S. 2009. Stable warm tropical climate through the Eocene Epoch. Geology, 35: 211-214.

Perch-Nielsen, K. 1985. Mesozoic calcareous nannofossils. In: Bolli, H.M., Saunders, J.B. \& Perch-Nielsen, K. (Eds), Plankton Stratigraphy. Cambridge University Press, Cambridge, pp. 329-426.

Romein, A.J.T. 1979. Lineages in early Paleogene calcareous nannoplankton. Utrecht Micropaleontological Bulletin, 22: 1-231.

Schaub, H., Benjamini, C. \& Moshkovitz, S. 1995. Problems of multiple correlation: nummulites, planktic foraminifera, calcareous nannofossils. In: Schaub, H., Benjamini, C. \& Moshkovitz, S. (Eds), The Biostratigraphy of the Eocene in Israel, Part V. Schweizerischen Paleontologischen Abhandlungen, 117: 51-47.

Speijer, R.P. 1995. The late Paleocene benthic foraminiferal extinction as observed in the Middle East. In: Laga, P. (Ed.), Paleocene-Eocene boundary events. Poceedings of the co-ordinators meeting, Bulletin de la Societe Belge de Geologie, Bulletin van de Belgische Vereniging voor Geologie, 103: 267-280.

Tremolada, F. \& Bralower, T.J. 2004. Nannofossil assemblage fluctuations during the Paleocene-Eocene Thermal Maximum at Sites 213 (Indian Ocean) and 401 (North Atlantic Ocean): palaeoceanographic implications. Marine Micropaleontology, 52: 107-116.

Weinbaum-Hefetz, M., Benjamini, C. \& Moshkovitz, S. 2000. Genus Rhabdosphaera Haeckel across the lower/middle Eocene boundary at the Avedat Plateau in Israel: Biostratigraphy and possible paleoeoecological interpretation. In: Schmitz, B., Sundquist, B. \& 
Calcareous nannofossil assemblage changes, central Israel

Andreasson, F.P. (Eds), Early Paleogene warm climates and biosphere dynamics, short papers and extended abstracts, GFF, 122: $176-177$.

Young, J.R., Bergen, J.A., Bown, P.R., et al. 1997. Guidelines for coccolith and calcareous nannofossil terminology. Palaeontology, 40: 875-912.

Young, J.R. \& Bown, P.R. 1997. Cenozoic calcareous nannoplankton classification. Journal of Nannoplankton Research, 19: 36-47.
Zachos, J.C., Dickens, G.R. \& Zeebe, R.E. 2008. An early Cenozoic Perspective on greenhouse warming and carbon-cycle dynamics. Nature, 451: 279-283.

Zachos, J., Pagani, M., Sloan, L., Thomas, E. \& Billups, K. 2001. Trends, Rhythms, and Aberrations in Global Climate $65 \mathrm{Ma}$ to Present. Science, 292: 686-693. 


\section{GEGFACETS}

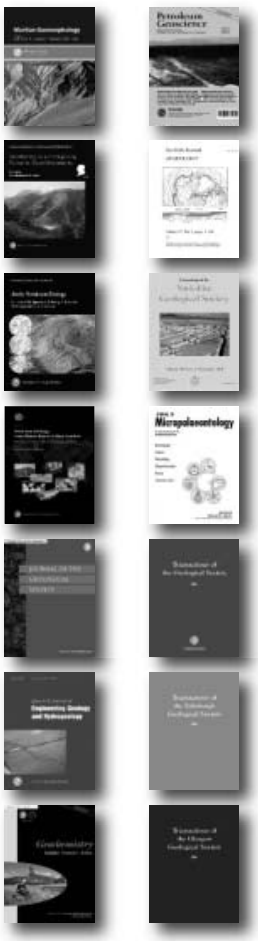

\section{What is the Lyell Collection?}

Launched in 2007 the Lyell Collection is an online collection comprising the Society's journal titles, Special Publications and key book series. Cutting edge science sits alongside important historical material, all captured and presented to the highest electronic standards and benefiting from the extensive functionality of HighWire Press' H2O platform.

With 240000 peer-reviewed pages, 25000 articles and 1000 volumes, the Lyell Collection is an invaluable tool for the researcher and student alike.

- Full text in HTML and PDF format

- Actively linking to cited references

- Free public access to alerts, search functions and abstracts

- Selected open access articles

- Hosted by Highwire Press

\section{The Geological Society}

The Geological Society of London was founded in 1807 and is the UK national society for geosciences, with over 10000 members. It is a global leader in Earth science publishing, dedicated to providing a high-quality service throughout the world.
The Society is collaborating with Elsevier to launch a Lyell Collection module on Geofacets. Selected titles will be available on Geofacet's searchable database of georeferenced geological maps that enables geoscientists working in the early stages of upstream exploration to assess a region's or basin's geological characteristics.

- Intuitive search features designed for geoscientists

- Map overlays

- Access to thousands of georeferenced maps

- Links to associated articles

- For further information please contact sales@geolsoc.org.uk

\section{Special Publication archives}

Online archives of the first 300 volumes of the Geological Society's Special Publications are now available for sale on a one-off, perpetual access basis. Prices include a $10 \%$ discount for those purchasing the full archive (volumes 1-300)

\section{New titles}

Two new archival titles will be launched and made available to Lyell Collection Complete subscribers at no additional charge.

- Transactions of the Edinburgh society

- Transactions of the Glasgow society

\section{Lyell Collection for libraries 2012: content and prices}

\begin{tabular}{|c|c|c|c|c|c|}
\hline TITLE & 2012 Content & Access options & UK price $\mathrm{f}^{*}$ & RoW price $f^{*}$ & RoW price US\$* \\
\hline \multirow[t]{3}{*}{ Lyell Collection Complete } & \multirow[t]{3}{*}{ All content } & Online & $\mathrm{f3,661}$ & $f 3,889$ & $\$ 7,778$ \\
\hline & & Online + Print & $£ 4,119$ & $f 4,375$ & $\$ 8,750$ \\
\hline & & Online + Special Publications Print** & $\mathrm{f} 3,911$ & f4,139 & $\$ 8,278$ \\
\hline \multirow[t]{2}{*}{ Special Publications } & \multirow[t]{2}{*}{$360+$ volumes } & Online & 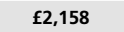 & $£ 2,250$ & $\$ 4,499$ \\
\hline & & Online + Print & $£ 2,427$ & $f 2,531$ & $\$ 5,061$ \\
\hline Engineering Geology Special Publications & $25+$ volumes & \multicolumn{4}{|l|}{ Available as part of Lyell Collection Complete only } \\
\hline Memoirs & $36+$ volumes & \multicolumn{4}{|l|}{ Available as part of Lyell Collection Complete only } \\
\hline Petroleum Geology Conference Series & 4 volumes & \multicolumn{4}{|l|}{ Available as part of Lyell Collection Complete only } \\
\hline \multirow{2}{*}{ Journal of the Geological Society } & \multirow[t]{2}{*}{1845 to current } & Online & f842 & f935 & $\$ 1,871$ \\
\hline & & Online + Print & f948 & f1,052 & $\$ 2,105$ \\
\hline \multirow[t]{2}{*}{ Quarterly Journal of Engineering Geology and Hydrogeology } & \multirow[t]{2}{*}{1967 to current } & Online & $\mathbf{f 3 9 9}$ & $\mathbf{f 4 4 7}$ & $\$ 893$ \\
\hline & & Online + Print & $\mathbf{f 4 4 9}$ & f502 & $\$ 1,005$ \\
\hline \multirow[t]{2}{*}{ Geochemistry: Exploration, Environment, Analysis } & \multirow[t]{2}{*}{2001 to current } & Online & f215 & f243 & $\$ 487$ \\
\hline & & Online + Print & f242 & f274 & $\$ 548$ \\
\hline \multirow[t]{2}{*}{ Petroleum Geoscience } & \multirow[t]{2}{*}{1995 to current } & Online & f361 & f361 & $\$ 722$ \\
\hline & & Online + Print & f406 & f406 & $\$ 813$ \\
\hline \multirow[t]{2}{*}{ Scottish Journal of Geology } & \multirow[t]{2}{*}{1965 to current } & Online & $\mathbf{f 2 0 0}$ & $\mathbf{f 2 0 0}$ & $\$ 400$ \\
\hline & & Online + Print & $\mathbf{f 2 2 5}$ & f225 & $\$ 450$ \\
\hline \multirow[t]{2}{*}{ Proceedings of the Yorkshire Geological Society } & \multirow[t]{2}{*}{1837 to current } & Online & f162 & f162 & $\$ 324$ \\
\hline & & Online + Print & f183 & f183 & $\$ 365$ \\
\hline \multirow[t]{2}{*}{ Journal of Micropalaeontology } & \multirow[t]{2}{*}{1991 to current } & Online & f184 & f184 & $\$ 368$ \\
\hline & & Online + Print & f207 & f207 & $\$ 413$ \\
\hline Transactions of the Geological Society & 1811 to 1856 & Available as part of Lyell Collection Complete only & & & \\
\hline Transactions of the Edinburgh Geological Society & 1870 to 1963 & Available as part of Lyell Collection Complete only & & & \\
\hline Transactions of the Glasgow Geological Society & 1863 to 1965 & Available as part of Lyell Collection Complete only & & & \\
\hline \multicolumn{6}{|l|}{ Special Publications Archive } \\
\hline Archive 1 & Volumes $1-100$ & Online & $f 2,500$ & $f 2,500$ & $\$ 5000$ \\
\hline Archive 2 & Volumes $101-200$ & Online & $£ 2,500$ & $£ 2,500$ & $\$ 5000$ \\
\hline Archive 3 & Volumes 201-300 & Online & $f 2,500$ & $£ 2,500$ & $\$ 5000$ \\
\hline Archive 1 - 3 & Volumes 1-300 & Online & $\mathrm{f} 6,750$ & $f 6,750$ & $\$ 13,500$ \\
\hline
\end{tabular}

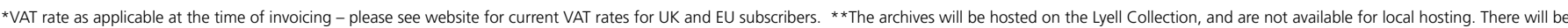
no ongoing maintenance or access charge. Prices are for single sites only. Please apply for multi-site and consortial pricing.

To order the Lyell Collection or individual journal titles, or request further information or a free trial, please contact:

In UK and Europe: Email: geologicalsociety@accucoms.com Telephone: +31 715247630

In Korea: Email: jkim1@ebsco.com Telephone: 82-2-598-2571 (ext. 230)

USA and Canada: Email: geologicalsociety@pcgplus com Telephone: +16173954065

In Japan: Email: kobayashi@ebsco.co.jp Telephone: +81 (0)3 53275273

In Taiwan, Hong Kong, Macau, SE Asia: Email: salestw@ebsco.com Telephone: +886 28786060

All other regions: Email: sales@geolsoc.org.uk Telephone: +44 (0)1225 445046

In South America: Email info@dotlibcom Telephone: +55(21) 3431-3430

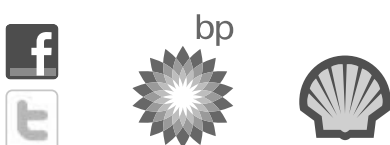

Foundation Sponsors 